\title{
MEDIA PEMBELAJARAN TENTANG KLASIFIKASI BINATANG BERBASIS VIDEO ANIMASI 3 DIMENSI DI SMP NEGERI 2 WANGON
}

\author{
Debby Ummul Hidayah ${ }^{1}$, Pungkas Subarkah ${ }^{2}$ \\ ${ }^{1,2}$ Program Studi Sistem Informasi, Fakultas Ilmu Komputer, Universitas Amikom Purwokerto \\ Jl. Letjen Pol Sumarto Watumas Purwanegara Purwokerto, Banyumas 53123 \\ Email : ${ }^{1}$ debbyummul@amikompurwokerto.ac.id, ${ }^{2}$ subarkah@amikompurwokerto.ac.id
}

\begin{abstract}
ABSTRAK
Media menjadi salah satu faktor penunjang yang dapat mempengaruhi kesuksesan dalam pendidikan. Sistem pendidikan yang hanya memberikan ceramah saja cenderung membuat siswa menjadi cepat bosan. Bahkan para siswa sering mengantuk ketika guru menjelaskan. Akibatnya ilmu yang disampaikan guru tidak terserap dengan optimal. Hal ini membuktikan bahwa siswa cenderung tertarik dengan penjelasan berupa gambar visual. Diharapkan dengan adanya media berbasis video animasi 3 dimensi untuk menjelaskan materi tentang klasifikasi binatang khususnya di SMP Negeri 2 Wangon. Media sendiri merupakan suatu komponen yang dapat merangsang pikiran seseorang sehingga memiliki keinginan untuk belajar. Metode dalam pembuatan video animasi 3 dimensi, dengan melalui tahap pra produksi,tahap produksi dan tahap pasca produksi. Dalam pembuatan video 3 dimensi menjelaskan tentang klasifikasi binatang yang terdiri dari pisces, amphibia, reptilia, aves, dan mamalia. Masingmasing dijelaskan secara singkat dan terdapat contohnya masing-masing. Hasil akhir dalam implementasi video 3 dimensi di SMP Negeri 2 Wangon telah berhasil dan antusias siswa serta guru, harapannya agar ada perbaiki dalam pembuatan video animasi 3 dimensi khususnya dalam percontohan binatang.
\end{abstract}

Keyword : Video animasi 3 dimensi, media pembelajaran, klasifikasi binatang

\begin{abstract}
The media is one of the supporting factors that can influence success in education. An education system that only gives lectures tends to make students get bored quickly. Even students are often sleepy when the teacher explains. As a result, the knowledge delivered by the teacher is not optimally absorbed. This proves that students tend to be interested in explanations in the form of visual images. It is hoped that the existence of a 3-dimensional animated video-based media to explain material about animal classification, especially in SMP Negeri 2 Wangon. Media itself is a component that can stimulate a person's mind so they have the desire to learn. The method in making 3 dimensional video animation, through the pre-production, production and post-production stages. In making 3dimensional video, it explains the classification of animals consisting of pisces, amphibians, reptiles, aves, and mammals. Each is briefly explained and there are examples of each. The final results in the implementation of 3 dimensional video at SMP Negeri 2 Wangon have been successful and enthusiastic students and teachers, hoping that there will be improvements in making 3-dimensional animated videos, especially in animal modeling.
\end{abstract}

\section{Keyword: 3 dimension of animated video, learning media, animal classification}

Author Korespondensi (Debby Ummul Hidayah)

Email :debbyummul@amikompurwokerto.ac.id 


\section{PENDAHULUAN}

Pendidikan merupakan fondasi untuk membangun generasi yang unggul dan kompeten. Sudah semestinya pendidikan perlu melihat dengan jelas khususnya terkait media pembelajaran yang digunakan. Media dapat menjadi salah satu faktor keberhasilan dalam mekanisme pembelajaran, sebab dengan adanya media dapat menjadikan siswa untuk lebih aktif serta proses belajar mengajar menjadi lebih bermakna [1]. Menurut Gagne dalam [1] media menjadi aset yang dinilai penting sebagai penunjang untuk meningkatkan peran aktif siswa agar mau belajar. Dengan demikian, media pembelajaran di kelas perlu diperhatikan oleh para guru ketika melakukan proses belajar mengajar.

Sebelum perkembangan teknologi semakin luas seperti saat ini, media yang kerap kali digunakan sebagai penunjang pembelajaran yaitu kapur, papan tulis, dan buku cetak. Media tersebut sering disebut sebagai pembelajaran konvensional. Guru mengajar siswa dengan model ceramah dan menuliskan hal-hal penting pada papan tulis menggunakan kapur. Adapun buku paket biasanya berupa lembar kerja siswa atau disingkat dengan LKS, yang berisi materi dan latihan soal. Buku cetak lainnya dapat dipinjam oleh siswa dengan mencarinya terlebih dahulu di perpustakaan sekolah. Dengan kemajuan zaman yang sudah semakin modern, media tersebut perlahan beralih menggunakan media berbasis teknologi. Seperti penggunaan LCD proyektor untuk menampilkan materi pada layar dengan laptop atau komputer. Juga penggunaan microphone sebagai alat bantu pengeras suara. Meskipun demikian papan tulis pun masih kerap digunakan. Hanya saja sudah berganti menjadi papan tulis putih dan menggunakan spidol.

Dalam pembelajaran, seorang guru perlu memperhatikan dalam penyampaian materi di kelas. Penyampaian materi hanya secara lisan saja cenderung membuat jenuh para siswa di kelas. Selain itu, mereka juga cenderung akan cepat merasa bosan dan mengantuk. Jika hal tersebut terus berlanjut dapat menjadikan siswa menjadi tidak mau aktif dan memiliki motivasi belajar yang rendah [2]. Selain itu, materi yang dapat diserap hanya sekian persen saja. Pun akan cepat lupa jika tidak dipelajari kembali. Menurut Edgar Dale dalam [3] menjelaskan bahwa pembelajaran hanya dengan mendengarkan guru saja akan membuat pengalaman belajar siswa sebesar 20\%. Akan berbeda apabila menggunakan media visual, yaitu dapat meningkatkan pengalaman belajar siswa 10\% sehingga total menjadi $30 \%$. Pengalaman belajar ini berpengaruh terhadap penguasaan konsep materi yang diberikan oleh guru. Jika siswa tidak mampu menyerap ilmu yang disampaikan maka dapat menyebabkan materi menjadi susah untuk dikuasai.

SMP Negeri 2 Wangon menjadi salah satu sekolah yang telah mengimplementasikan teknologi. Dari pengamatan yang dilakukan, di sekolah tersebut telah memiliki LCD proyektor. Akan tetapi masih kurang untuk dimanfaatkan. Jika dikaitkan dengan pembelajaran, maka penggunaan media tersebut menjadi salah satu solusi sebagai media dalam penyampaian materi. Di samping itu, para guru pun sebagian telah memiliki laptop yang dijadikan sebagai perangkat untuk membantu dalam pekerjaan. Adanya fasilitas yang telah cukup memadai tersebut, maka dapat menjadi salah satu upaya untuk mengembangkan media pembelajaran yang lebih bersifat digital dengan bantuan teknologi.

Dengan pembelajaran yang menarik maka dapat merangsang pikiran para siswa dalam menyerap ilmu yang disampaikan. Dalam hal ini, media pembelajaran yang efektif dapat membantu siswa dalam meningkatkan daya pikir mereka. Di SMP Negeri 2 Wangon terdapat salah satu mata pelajaran yaitu biologi. Mata pelajaran tersebut memiliki cakupan materi yang cukup banyak. Selain itu, adanya gambar dapat menjadi penjelas terhadap materi yang dipelajari. Saat ini, materi tersebut hanya tertulis saja pada buku. Pun penjelasan gambar yang ada terkadang masih kurang jelas. Jika gambar maupun tulisan tersebut terdapat goresan warna maupun animasi tentunya akan lebih menarik sebagai media pembelajaran. Sebagai contoh pada materi tentang klasifikasi binatang. Materi tersebut akan lebih menarik jika terdapat visualisasinya. Yaitu dengan membuat objek binatang menjadi lebih nyata dan hidup. Binatang dapat diklasifikasikan menjadi 5 yaitu pisces, mamalia, amphibia, aves, dan reptilia. Pisces merupakan kelompok ikan yang berkembangbiak dengan cara bertelur. Mamalia merupakan binatang menyusui, amphibia merupakan binatang dengan habitat berada di darat maupun air, aves merupakan binatang yang memiliki sayap (burung), dan reptilia merupakan dapat disebut 
binatang melata dan berdarah dingin. Visualisasi tersebut dapat diwujudkan menjadi video animasi 3 dimensi. Dengan video animasi 3 dimensi, maka para siswa dapat mengetahui seperti apa deskripsi dan contoh dari pada kelima klasifikasi binatang tersebut. Selain itu dengan melihat visualisasinya secara langsung maka dapat meningkatkan daya ingat para siswa. Menurut [4] menjelaskan bahwa dengan animasi 3 dimensi sebagai alat bantu dalam pembelajaran dapat meningkatkan ketertarikan bagi yang melihatnya sehingga mereka akan mudah mengerti dari isi yang disampaikan pada video bersangkutan.

Berdasarkan analisis permasalahan di atas, peneliti tertarik untuk membuat media berbasis video animasi 3 dimensi untuk menjelaskan materi tentang klasifikasi binatang khususnya di SMP Negeri 2 Wangon. Media sendiri merupakan suatu komponen yang dapat merangsang pikiran seseorang sehingga memiliki keinginan untuk belajar atau rasa ingin tahu [5]. Video merupakan suatu teknik untuk menggabungkan audio visual [6]. Sedangkan animasi dapat diartikan sebagai gambar bergerak yang sebelumnya merupakan desain dari pengolahan gambar tangan [7]. Adapun animasi 3 dimensi adalah suatu bentuk yang dapat dilihat dari berbagai arah [8]. Sehingga video animasi 3 dimensi adalah suatu video yang berisi gambar bergerak dengan memiliki alur dan dapat merangsang pikiran para siswa. Adapun video animasi 3 dimensi ini dapat dijadikan sebagai penunjang bagi guru untuk menyampaikan materi dan bagi siswa sebagai penunjang untuk memudahkan pemahaman akan materi dari guru. Sehingga guru tidak perlu mengulang-ulang materi yang sudah pernah dijelaskan. Di samping itu, media berupa video animasi dapat menjadi sumbangsih dalam memajukan pendidikan [9].

Penelitian sebelumnya pernah dilakukan oleh [10] dengan fokus pada pembuatan animasi 3 dimensi tentang sejarah pembentukan yayasan Almuslim. Video tersebut dibuat untuk memberikan pemahaman kepada para responden khsuusnya untuk menayangkan sejarah terbentuknya yayasan Almuslim.

Selanjutnya penelitian sebelumnya juga pernah dilakukan oleh [11] [12] [13] menjelaskan bahwa media pembelajaran berbasis video animasi 3 dimensi dapat menjadi salah satu daya tarik siswa untuk lebih meningkatkan prestasi belajar, sekaligus menjadi salah satu inovasi baru dalam media pembelajaran. Serta proses pembelajaran dapat menjadi lebih efektif.

\section{METODOLOGI \\ Teknik Pengumpulan Data}

Teknik pengumpulan data merupakan suatu langkah yang dilakukan oleh peneliti guna memperoleh data penelitian kemudian mengolahnya dan menghasilkan informasi yang relevan. Berikut dijabarkan teknik pengumpulan data yang peneliti gunakan:

1. Observasi

Observasi berarti mengamati secara langsung terhadap lokasi penelitian. Dalam penelitian ini, peneliti meneliti terkait proses pembelajaran yang diberlakukan di SMP N 2 Wangon, Kabupaten Banyumas.

2. Studi Pustaka

Dalam hal ini, peneliti melakukan telaah terhadap literatur-literatur yang berkaitan dengan masalah penelitian. Untuk menjadi bahan kajian literatur tersebut, peneliti memanfaatkan beberapa media sebagai sumber guna memperoleh informasi yang dibutuhkan. Diantaranya buku-buku yang berkaitan dengan topik penelitian, jurnal ilmiah yang tengah dipublikasikan, maupun contoh karya ilmiah peneliti lain yang berguna sebagai acuan memperoleh informasi.

\section{Alat dan Bahan Penelitian}

Guna mendukung penelitian, peneliti memerlukan beberapa alat dan bahan penelitian sebagai fasilitas penunjang penelitian, antara lain:

1. Alat dan Bahan

a. Perangkat Keras (Hardware)

Guna menyelesaikan permasalahan penelitian, peneliti memanfaatkan media perangkat keras berupa laptop yang berguna untuk mendesain, membuat video animasi 3D, dan menyelesaikan laporan. Media tambahan lainnya adalah printer untuk mencetak laporan penelitian. Kemudian sambungan internet yang akan digunakan untuk menjalankan web browser guna mendukung pencarian literatur.

b. Perangkat Lunak (Software) 
Untuk terciptanya video animasi 3D tentang klasifikasi binatang, dibutuhkan software seperti:

1) $3 \mathrm{D}$ Max

2. Bahan

2) Adobe Photoshop

Bahan konten untuk video animasi 3D yaitu buku ajar mata pelajaran IPA (Ilmu Pengetahuan Alam) dan artikel yang bersumber dari internet.

\section{Metode Pengembangan Sistem}

Metode penelitian dapat dijelaskan sebagai suatu teknik ilmiah guna mencari data dan informasi kemudian mengolah data penelitian tersebut agar memiliki tujuan dan fungsi khusus [14]. Oleh sebab itu, sebelum penelitian dilakukan, peneliti perlu menelaah terlebih dahulu metode yang tepat guna menghasilkan keluaran untuk mencapi tujuan yang diharapkan. Dalam penelitian ini, peneliti menggunakan metode pengembangan sistem yang diusulkan oleh Andy Beane [15] sebagai metode pengembangan dari projek animasi yang dibuat. Terdapat 3 tahapan yang harus dilakukan. Dimulai dengan tahap pra produksi, selanjutnya produksi, dan pasca produksi.

\section{Tahap Pra Produksi}

Tahap pra produksi dapat dikatakan sebagai tahapan pertama yang nantinya berguna sebagai bahan untuk membuat animasi. Pada tahap ini ditentukan memiliki beberapa fase penting yang perlu diperhatikan, diantaranya:

1. Ide Cerita

Ide cerita merupakan gagasan pokok dari film animasi yang dibuat. Adapun ide cerita dalam video animasi ini adalah tentang klasifikasi binatang.

2. Naskah

Selanjutnya dilakukan pembuatan naskah yang akan memberikan gambaran mengenai alur cerita.

3. Storyboard

Soryboard yang merupakan penerjemahan serangkaian gambar yang memiliki arahan serta dialog dengan urutan yang jelas .dalam pembuatan animasi 3 dimensi.

\section{Tahap Produksi}

Tahap produksi menjadi tahapan kedua setelah pengumpulan data yang dibutuhkan pada tahap pra produksi berhasil dikumpulkan. Peneliti melakukan tahap produksi dengan mencoba membuat animasi 3 dimensi sesuai dengan kebutuhan dalam penelitian. Ada beberapa tahapan untuk menjalankan proses pembuatan animasinya, yaitu:

1. Modeling

Tahap modeling merupakan proses untuk membuat suatu representasi geometri dari suatu objek. Selanjutnya objek tersebut dapat dilihat secara vertikal, horisontal, maupun diputar baik 90 derajat atau 180 derajat.

2. Texturing

Tahapan selanjutnya adalah texturing yaitu suatu tahapan untuk membuat sekaligus memberikan tekstur berupa warna pada objek yang sudah dibuat pada tahap modeling. Dengan pemeberian warna yang sesuai maka mudah untuk diilustrasikan secara visual.

3. Rigging

Tahapan ketiga yaitu melakukan rigging. Fase tersebut dilakukan sebagai tahapan memberi tulang pada masing-masing objek. Sekaligus menelaah tiap objek apakah berhasil digerakkan atau sebaliknya dalam proses pembuatan animasi 3 dimensi.

4. Animasi

Kemudian pada tahapan keempat, peneliti mulai melakukan pembuatan animasinya. Dalam tahap ini setiap objek tengah berhasil digerakkan. Peneliti mencocokkan gerakan tersebut berdasarkan teks atau skenario dari storyboard pada jalan cerita tentang klasifikasi binatang.

5. Lighting

Untuk tahapan lighting, dilakukan proses untuk pemberian cahaya terhadap tiap animasi yang sudah jadi. Sehingga animasi tersebut mampu menciptakan suasana dengan atmosfir yang enak dipandang bagi mata.

6. Rendering

Terakhir yaitu melakukan proses rendering. Pada tahap terakhir menjadi tahap untuk mengkalkulasi dari prosesproses yang telah dilakukan sebelumnya. Yakni dari tekstur, pemberian cahaya, maupun mengerakkan masing-masing obejk.

\section{Tahap Pasca Produksi}

Selanjutnya untuk tahap pasca produksi dapat dilakukan dengan 3 fase yang meliputi: 
1. Fase compositing

Pada fase ini dilakukan proses pemberian lapisan sehingga tercipta objek visual yang lebih baik.

2. Fase koreksi warna

Kemudian untuk fase kedua yaitu fase koreksi warna, adalah untuk menyesuaikan semua warna pada tiap-tiap objek. Dengan demikian, animasi dengan pemberian warna tersebut dapat tercapai sesuai kebutuhan dan menjadikan hasil animasi yang lebih baik.

3. Fase akhir

Tahap terakhir yaitu fase akhir yang dapat dinyatakan sebagai fase penggabungan dari semua animasi yang sudah siap sebelumnya. Sekaligus pemberian audio atau suara. Setelah berhasil digabungkan langkah selanjutnya dilakukan konversi ke dalam ekstensi .mp4.

\section{HASIL DAN PEMBAHASAN}

\section{Tahap Pra Produksi}

Media belajar menggunakan suatu media seperti video animasi 3 dimensi dapat menjadi solusi yang cukup efektif sebagai media penyampaian ilmu kepada paraa siswa. Di samping itu pada video animasi memilki tampilan yang lebih hidup sehingga akan mudah untuk memahaminya. Juga dilengkapi dengan adanya suara sebagai penjelas dari video bersangkutan. Untuk menghasilkan unsur-unsur yang relevan tersebut, berikut merupakan fase-fase dalam tahap pra produksi yang perlu dilakukan, diantaranya:

1. Ide atau cerita dalam video 3D Klasifikasi

Binatang.

Dalam fase ini cerita pada video 3D tentang klasifikasi binatang, peneliti melakukan wawancara dua arah dengan guru mata pelajaran biologi SMP Negeri 2 Wangon. Dari hasil wawancara kepada guru biologi di SMP Negeri 2 Wangon, bahwa materi pada video 3D klasifikasi binatang, harus menyesuaikan dengan kurikulum yang diajarkan di SMP Negeri 2 Wangon.

2. Naskah Video 3D Klasifikasi Binatang

Fase kedua dalam tahap pra produksi yaitu penulisan naskah dilakukan setelah ide atau cerita sudah disetujui oleh pihak guru Biologi SMP Negeri 2 Wangon. Penulisan naskah dalam pembuatan video 3 Dimensi
Klasifikasi Binatang, meliputi materi pokok tentang klasifikasi binatang, yaitu PARAM atau jika dijabarkan menjadi Pisces, Amphibi, Reptilia, Aves dan Mammalia. Kemudian tiap klasifikasi binatang dijabarkan penjelasan serta diberikan contoh hewan yang akan dimasukan dalam komponen video 3D klasifikasi binatang. Sedangkan dalam membuat naskah dilakukan melalui 4 tahap. Pertama membuat pemikiran akan judul, kemudian nama pengarang serta materi/topik yang dibuat. Kedua melakukan persiapan yaitu mendeskripsikan masing-masing klasifikasi binatang yang nantinya akan diuraikan. Kemudian pada tahap ketiga melakukan proses pengolahan terkait pengenalan PARAM pada klasifikasi binatang. Terakhir melakukan penyajian berisi tentang penjelasan tiap hewan pada klasfikasi binatang. Adapun dalam membuat naskah, sebelumnya telah melalui validasi ahli media dan juga guru mata pelajaran biologi yang berperan sebagai pengampu materi tersebut.

3. Storyboard

Pada bagian storyboard merupakan bagian dari sketsa yang dilengkapi keterangan sebagai panduan dalam pembuatan video animasi 3D klasfikasi binatang.

\section{Tahap Produksi}

1. Modelling

Pada tahap ini tiap objek akan direpresentasikan ke dalam bentuk geometri yang nantinya dapat diputar berdasar arah yang diinginkan. Berikut merupakan salah satu pembuatan modelling pada badan salah satu hewan.

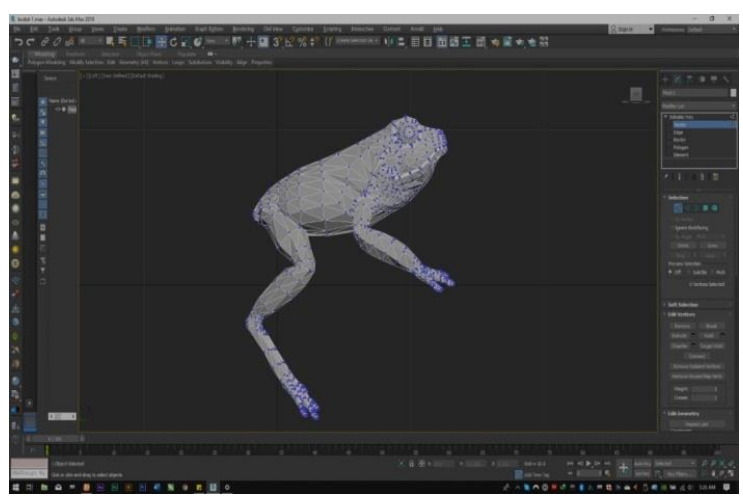

Gambar 1. Modelling badan karakter hewan katak 


\section{Texturing}

Setelah melalui tahap modelling sekarang masuk ke dalam proses texturing. Pada proses ini pemberian texture atau warna pada sebuah objek dilakukan menggunakn 3D Max. Proses texturing pada program 3D Max dapat dibuat dengan beberapa tools yang ada, salah satunya pada tools texture adalah proses pemberian texture pada beberapa bagian (seperti gambar 4.2). Berikut ini salah satu gambar dalam proses texturing.

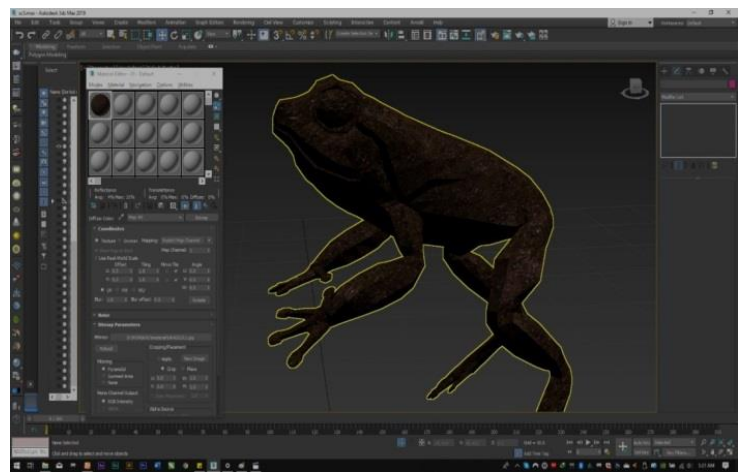

Gambar 2. Texturing pada hewan katak

3. Rigging

Proses selanjutnya setelah melalui proses texturing, ialah proses rigging. Pada proses ini, dilakukan pengontrolan terhadap masing-masing objek yang nantinya digerakkan dalam proses pembuatan animasi. Berikut gambar salah satu proses rigging dalam pembuatan video klasifikasi binatang.

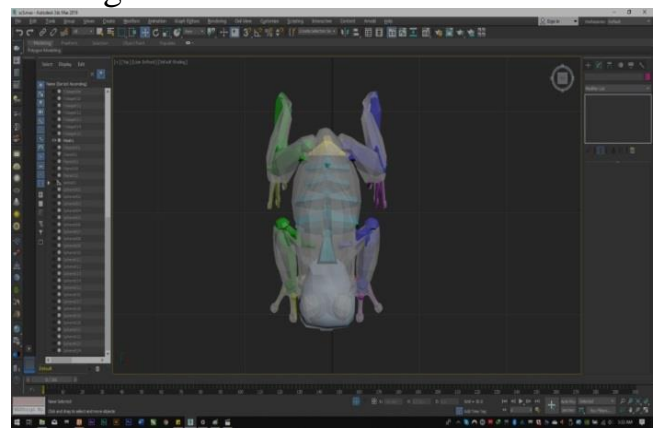

Gambar 3. Rigging pada hewan katak

4. Animasi

Proses animasi dilakukan setelah ketiga proses dari modelling, texturing, dan rigging telah selesai. Dimana proses animasi bertujuan untuk menggabungkan naskah dengan karakter yang dimuat dalam video klasifikasi binatang. Berikut merupakan gambar dalam proses animasi pembuatan video klasifikasi binatang.

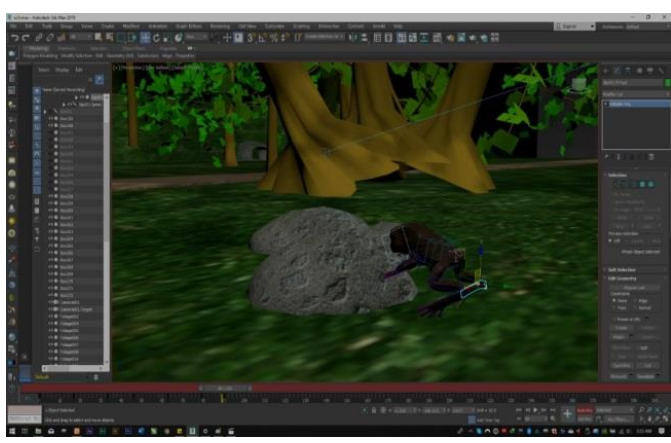

Gambar 4. Animasi hewan katak

5. Lighting

Pada proses lighting ialah proses dimana pemberian cahaya untuk setiap objek pada animasi. Dengan demikian objek akan lebih terlihat jelas dengan memperoleh suasana dengan objek gambar yang lebih nyata. Gambar 5 menunjukkan proses lighting pada animasi 3 dimensi tentang klasifikasi binatang.

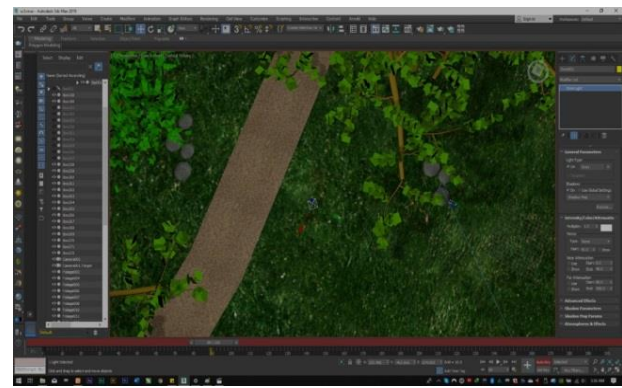

Gambar 5. Lighting video animasi animasi klasifikasi binatang

6. Rendering

Untuk tahap terakhir pada fase produksi adalah melakukan rendering. Pada tahap ini dapat melakukan render dengan menggabungkan unsur-unsur seperti gambar, video, maupun suara/audio. Gambar 6 menunjukkan proses rendering pada animasi 3D klasifikasi binatang.

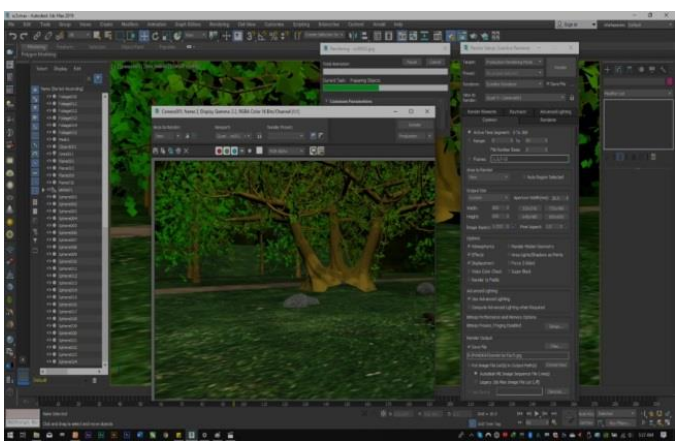

Gambar 6. Proses rendering video klasifikasi binatang

Tahap Pasca Produksi

1. Fase Compositing 
Setelah melalui tahap pra produksi dan tahap produksi dalam pembuatan video 3D klasifikasi binatang, selanjutnya ialah tahap pasca produksi. Yang pertama adalah fase compositing. Pada tahap ini semua objek pada animasi 3 dimensi tentang klasifikasi binatang digabungkan sehingga akan diperoleh hasil visual yang lebih baik. Gambar 7 merupakan tahap compositing pembuatan video.

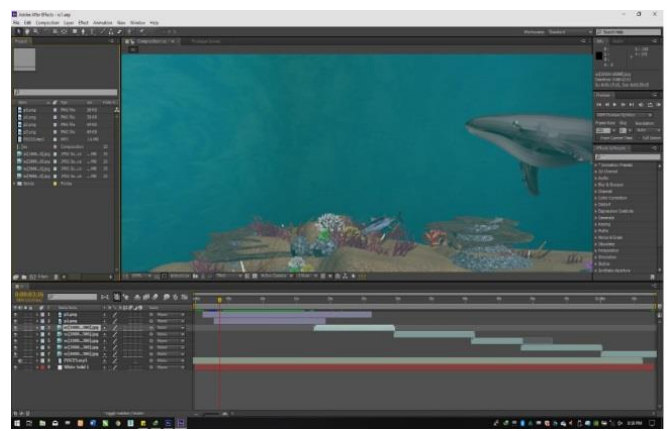

Gambar 7. Tahap compositing pembuatan video animasi 3 dimensi

2. Fase Koreksi Warna

Tahap berikutnya dalam tahapan pra produksi pembuatan video 3D klasifikasi binatang ialah fase koreksi warna, dimana tujuan fase ini untuk mengontrol dan menyempurnakan warna dalam animasi yang dibuat agar sempurna hasilnya. Berikut gambar proses fase koreksi warna dalam pembuatan animasi 3D klasifikasi binatang

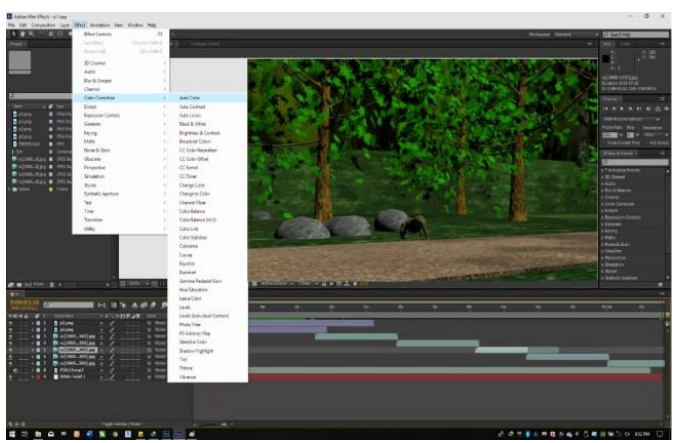

Gambar 8. Fase koreksi warna dalam pembuatan video

3. Fase Akhir

Kemudian dalam tahapan pra produksi, fase yang terakhir ialah bertujuan untuk mengecek semua bagian komponen dalam pembuatan video 3D klasifikasi binatang dan di convert ke format video sesuai durasi yang dibuat. Berikut proses dalam fase tahap akhir pembuatan video 3D klasifikasi binatang.

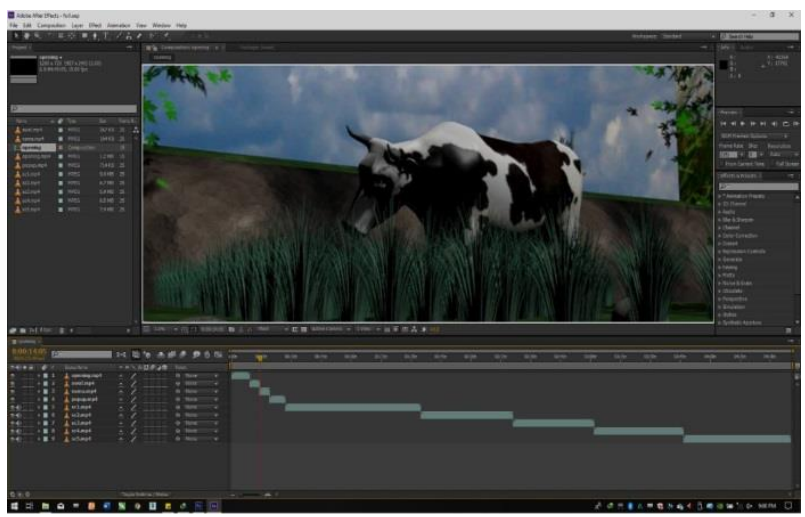

Gambar 9. Fase akhir video 3 dimensi klasifikasi binatang

\section{SIMPULAN DAN SARAN}

Setelah terselesaikannya penelitian ini, peneliti mengambil kesimpulan yaitu bahwa telah berhasil dibuat video animasi 3 dimensi tentang klasifikasi binatang khususnya bagi SMP Negeri 2 Wangon. Video tersebut telah dipresentasikan secara langsung tepatnya pada hari Rabu, 24 Juli 2019 di SMP Negeri 2 Wangon. Video animasi ini berdurasi 04.50 menit dengan isi video meliputi penjelasan klasifikasi, contoh binatang, dan daerah penyebarannya. Untuk pengembangan penelitian yang lebih relevan maka beberapa saran yang dapat diberikan untuk penelitian ini, diantaranya:

1. Penelitian ini diharapkan dapat digunakan dan dimanfaatkan dengan baik serta dapat dikembangkan untuk pembuatan video animasi 3 dimensi lain khususnya untuk mendukung pembelajaran dengan teori atau materi yang berbeda.

2. Bagi para peneliti selanjutnya, pengembangan penelitian tentang video animasi 3 dimensi ini, dapat dikembangkan menggunakan metode lainnya, seperti berbasis augmented reality.

\section{UCAPAN TERIMA KASIH}

Pertama, peneliti ucapkan terima kasih kepada Tuhan Yang Maha Esa, karena dengan karunia-Nya, jurnal ini dapat terselesaikan sesuai dengan tenggat waktu yang diberikan. Sehingga peneliti dapat menyumbangkan berupa ilmu pengetahuan dari hasil penelitian. Kemudian terima kasih juga untuk pihak Yayasan Amikom Purwokerto yang telah 
membantu peneliti baik materi dan non materi. Sehingga penelitian ini dapat diusulkan dan dapat dikembangkan. Bagi SMP Negeri 2 Wangon khususnya, semoga video animasi 3 dimensi tentang klasifikasi binatang ini dapat menjadi salah satu media belajar guna mendukung proses KBM di kelas. Juga untuk para siswa, semoga video animasi 3 dimensi tentang klasifikasi binatang ini dapat diterima dengan baik dan memberikan kemudahan dalam menelaah materi dari apa yang dijelaskan guru. Juga bagi pembaca jika sewaktu-waktu membaca hasil dari publikasi ilmiah ini, semoga bisa bermanfaat dan menjadi media untuk shared knowledge. Serta bagi semua pihak yang tidak bisa peneliti sebutkan satu per satu, terima kasih atas dukungan, motivasi, dan ilmu pengetahuan yang selama ini diberikan.

\section{REFERENSI}

[1] F. Muhibuddin, "Pengembangan Media Pembelajaran Berbasis Video Kelas IV Sekolah Dasar," J. Dimens. Pendidik. dan Pembelajaran, vol. 3, no. 1, pp. 2429, 2015.

[2] Viani Dui Sherly, Amrul Bahar, and Elvinawati, "Perbandingan Hasil Belajar Siswa Menggunakan Media Chemopoly Game Dan Tournament Question Cards," Alotrop, vol. 1, no. 1, pp. 55-59, 2017.

[3] Wahyuningsih, Jamaluddin, and Karnan, "PENERAPAN PEMBELAJARAN BIOLOGI BERBASIS MACROMEDIA FLASH DAN IMPLIKASINYA TERHADAP KETERAMPILAN METAKOGNITIF DAN PENGUASAAN KONSEP SISWA KELAS VIII SMPN 6 MATARAM," $J$. Pijar MIPA, vol. X, no. 1, pp. 41-46, 2015.

[4] J. Rori, S. Sentinuwo, and S. Karouw, "Perancangan Aplikasi Panduan Belajar Pengenalan Ortodonsia Menggunakan Animasi 3D," J. Tek. Inform. Univ. Sam Ratulangi, vol. 8, no. 1, pp. 3-7, 2016.

[5] Arda, S. Saehana, and Darsikin, "Pengembangan Media Pembelajaran Interaktif Berbasis Komputer Untuk Siswa Smp Kelas Viii," Mitra Sains, vol. 3, no. 1, pp. 69-77, 2015.

[6] P. Nurfathiyah, A. Mara, R. Siata, A. Farida, and Aprollita, "Pemanfaatan
Video Sebagai Media Penyebaran Inovasi Pertanian," J. Pengabdi. pada Masy., no. 52, pp. 30-36, 2011.

[7] F. Yuningsih, A. Hadi, and A. Huda, "Rancang Bangun Animasi 3 Dimensi Sebagai Media Pembelajaran Pada Mata Pelajaran Menginstalasi PC," $J$. Vokasional Tek. Elektron. Inform., vol. 2, no. 2, pp. $36-40,2014$.

[8] V. Waeo, S. . Arie, Lumenta, A. Brave, and Sugiarso, "Implementasi Gerakan Manusia Pada Animasi 3D Dengan Menggunakan Menggunakan Metode Pose to Pose," E-Journal Tek. Inform., vol. 9, no. 1, pp. 1-8, 2016.

[9] S. Ariyati and T. Misriati, "Perancangan Animasi Interaktif Pembelajaran Asmaul Husna," J. Tek. Komput. Amik Bsi, vol. II, no. 1, pp. 116-121, 2016.

[10] R. Indriani, T. M. Johan, and M. It, "Animasi Seharah Pembentukan Yayasan Almuslim Berbasis 3 Dimensi," J. TIKA Fak. Ilmu Komput. Univ. Almuslim, vol. 3, no. 3, pp. 36-45, 2018.

[11] P. P. R. Jerry, I. N. Jampel, and I. K. Sudarma, "Pengembangan Media Video Animasi Pada Pembelajaran Siswa Kelas IV Di Sekolah Dasar," $J$. EDUTECH Univ. Pendidik. Ganesha, vol. 6, no. 1, pp. 9-19, 2018.

[12] Suleman and F. Pernando, "Pembuatan Film Animasi 3D Dengan Muvizu Sebagai Media Pembelajaran Bahasa Inggris," Indones. J. Comput. Inf. Technol., vol. 3, no. 1, pp. 122-129, 2018.

[13] Syibral, Afizal, and D. Azmi, "Media Pembelajaran Interaktif Penanaman Sayuran Berbasis Animasi 3D," J. TIKA Fak. Ilmu Komput. Univ. Almuslim, vol. 4, no. 1, pp. 50-54, 2019.

[14] Sugiyono, Metode Penelitian \& Pengembangan (Research and Development). Bandung: Alfabeta, 2015.

[15] B. Setiawan, Alfitransyah, and I. Pradesan, "RANCANG BANGUN PEMBUATAN ANIMASI IKLAN LAYANAN MASYARAKAT 'MASA DEPAN TANPA NARKOBA,"” pp. 110, 2014. 